\title{
A Short Tour of Global Risks
}

Carmen M. Reinhart

This article is based on the author's Homer Jones Memorial Lecture delivered at the Federal Reserve Bank of St. Louis, Wednesday, June 25, 2019. (JEL E51, F3, G15, G28)

Federal Reserve Bank of St. Louis Review, Third Quarter 2020, 102(3), pp. 221-35. https://doi.org/10.20955/r.102.221-35

t's a pleasure and an honor to deliver the 2019 Homer Jones Lecture. What I'd like to do is examine global risks and connect those risks to the literature and work that I've done. The tour begins with some of the risks. This is not meant to be encyclopedic; but I will try to be brief so we can cover a lot of ground-some of the risks in the advanced economies and then, truly global in nature, move on to risks in emerging markets. I would note that, in the past, interest in emerging markets was really limited to traders that bought emerging market bonds and occasionally equity. But while in the early 1980s emerging markets accounted for about a third of global gross domestic product (GDP), now they account for about two-thirds of global GDP. So, it's really not possible to talk about the global economy without a full, rounded view of advanced and emerging economies.

I'll first focus on what I see as more short-term concerns and then talk about a long-term issue that keeps cropping up on my radar screen-something that I've been working on for a long time: What's going to happen with the U.S. dollar as a reserve currency? And I'll conclude there.

So, on to global risks in the advanced economies. I am going to start where much of the discussion has been recently, which is, of course, on issues relating to trade and globalization but also on issues relating to how much ammunition the advanced economies have in the event of a downturn. Let me start there.

Figure $1-$ not surprisingly, given the kind of work that I've done in the past on debtbasically shows the level of public debt from 1900 through the present for over 20 advanced economies. I want you to have three takeaways from this graph. Number one is pretty selfevident. Advanced economies as a whole have the highest levels of debt since World War II

Carmen M. Reinhart is the Minos A. Zombanakis Professor of the International Financial System at Harvard Kennedy School.

(c) 2020, Federal Reserve Bank of St. Louis. The views expressed in this article are those of the author(s) and do not necessarily reflect the views of the Federal Reserve System, the Board of Governors, or the regional Federal Reserve Banks. Articles may be reprinted, reproduced, published, distributed, displayed, and transmitted in their entirety if copyright notice, author name(s), and full citation are included. Abstracts, synopses, and other derivative works may be made only with prior written permission of the Federal Reserve Bank of St. Louis. 
Figure 1

Advanced Economies: Government Debt as a Percent of GDP, 1901-2019

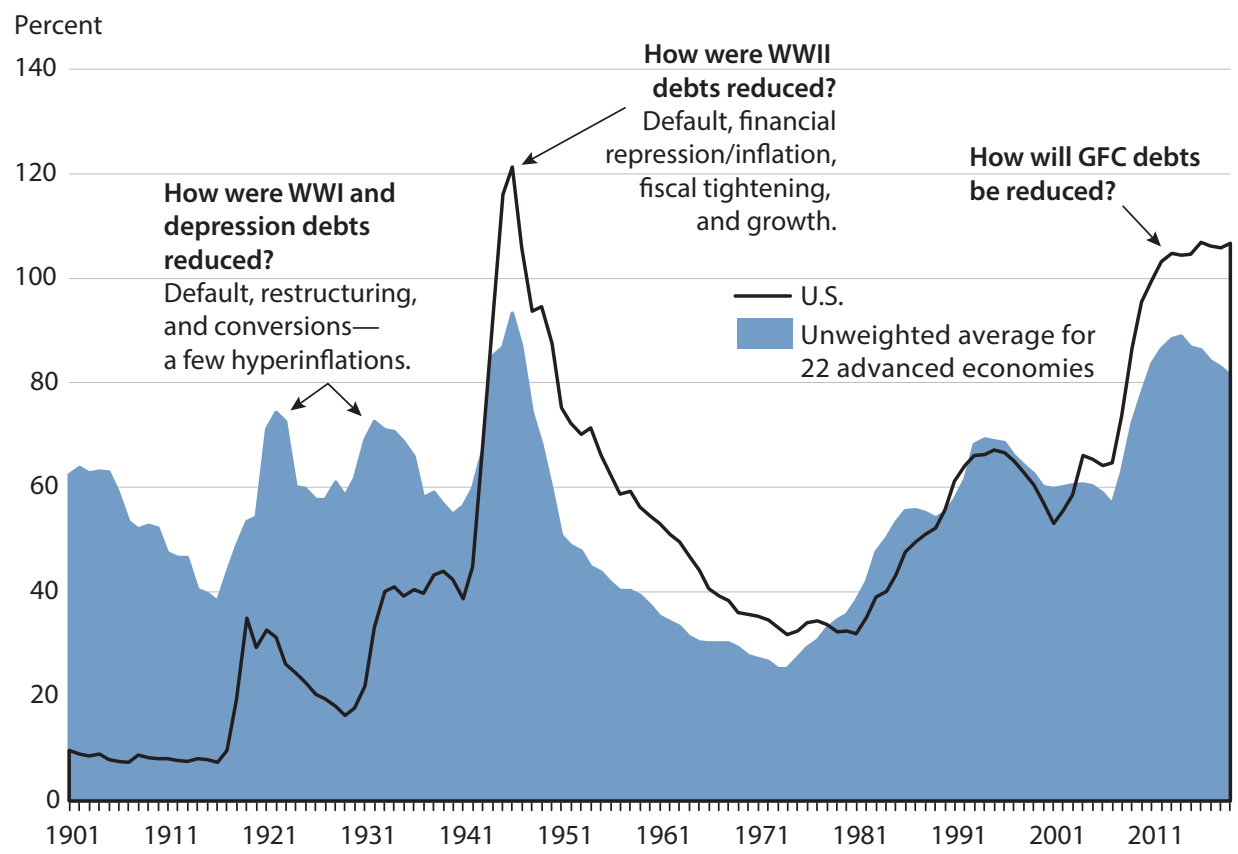

NOTE: GFC, global financial crisis.

collectively (blue shaded area). Number two, the United States (black line), which had more fiscal space than a number of advanced economies on the eve of the global financial crisis, has since had a bigger surge in debt and now has more sustained debt than what we've seen in other advanced economies.

Number three is tricky because you have to use your imagination: It's not what you see that should worry you; it's what you don't see that should worry you. This is strictly on-budget public debt, and therefore any off-balance-sheet items are not included. And two points on off-balance sheet items. At the end of World War II, public debt was the whole story. Private debt had been unwound through the Great Depression and the war, so the private sector was lean and mean. That applied to households. That applied to corporations. The whole story was what you see in this graph. In addition, advanced economies had much younger populations and very limited pension liabilities at that time, which you also don't see here.

The point that I am making is that, if Figure 1 already highlights that public indebtedness is a limiting factor (a limiting factor in how much fiscal space advanced economies have to cope with a downturn), I would add that limiting that fiscal space are further considerations in that private debt. In the context of the United States, I think there are some concerns on the corporate side. I will talk about that later. But generally, private debt levels are quite high in the advanced economies, certainly very high by postwar measures. And pension liabilities are understandably an issue unlike ever before, because of the aging structure of the popula- 


\section{Figure 2}

\section{Twin Deficits}

A. Twin balances: General government budget and current accounts relative to nominal GDP, average 2018-20 (percent)

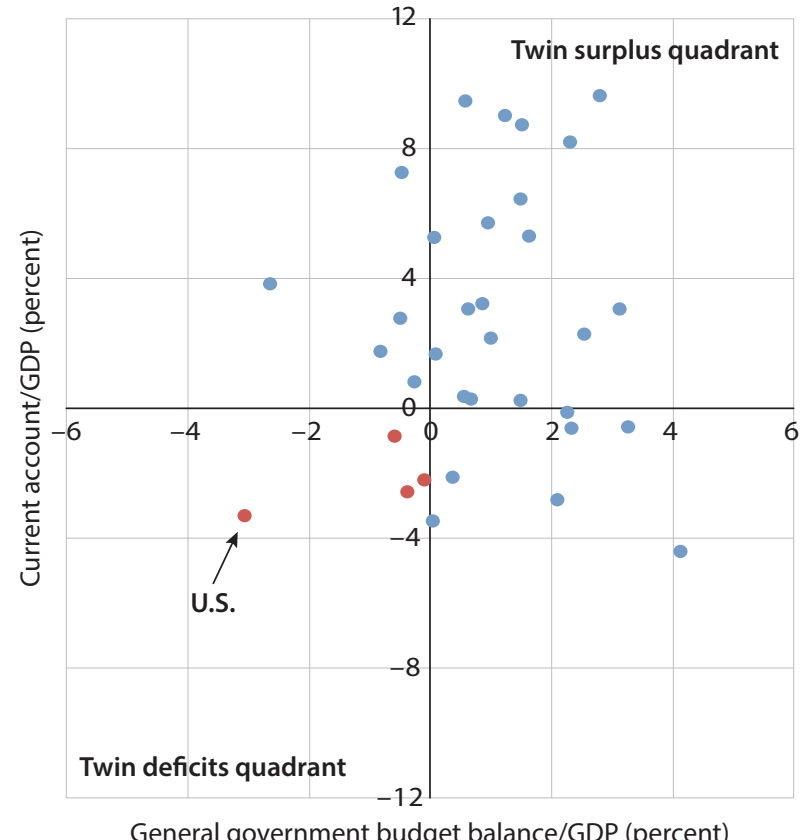

General government budget balance/GDP (percent)

\section{B. Gross government debt relative to GDP (percent)}

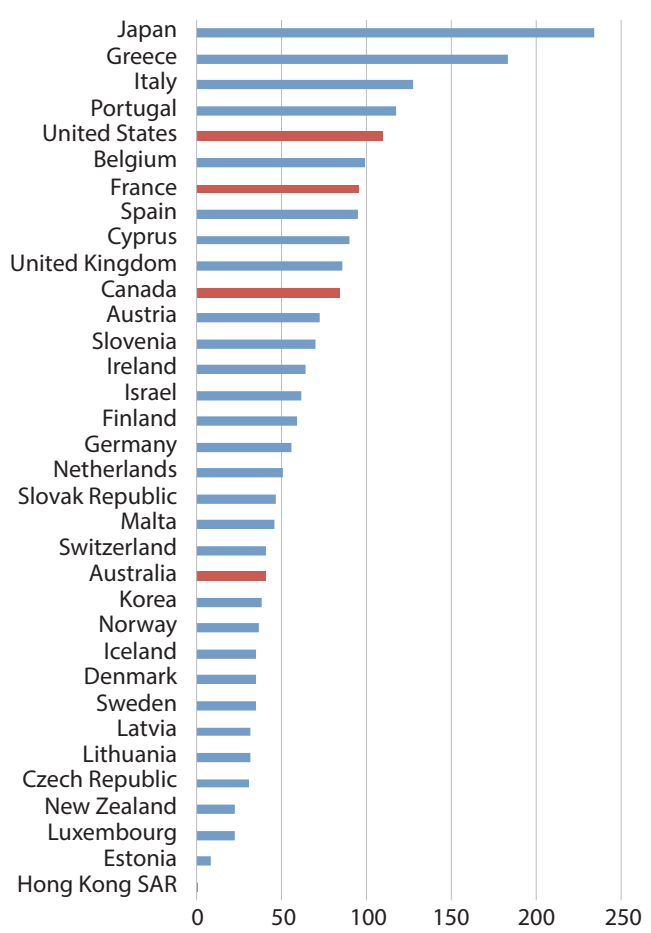

NOTE: Red dots and red bars indicate countries with twin deficits.

SOURCE: IMF and World Economic Outlook.

tion and the pension liabilities we've accumulated. So bottom line: Fiscal space is a lot more limited, notwithstanding many arguments out there that debts don't matter and deficits don't matter.

Note again the solid line in Figure 1. As I've mentioned, the United States has less fiscal space than the other advance economies because of the growing U.S. debt. The Congressional Business Office has done studies that basically show that in about a decade's time, even with interest rates remaining where they are or even with interest rates moving lower by about 50 basis points, the United States still has a debt sustainability issue arising - so bear that in mind.

I would also like to point out for the United States that, if we were an outlier in Figure 1 in our accumulation of debt, we're also an outlier in how quickly we are adding both public debt and external debt to our balance sheets. The bottom-left quadrant of Panel A of Figure 2 shows countries with twin deficits. Basically, a twin deficit means you have a current account deficit-you're borrowing from the rest of the world-and a fiscal deficit.

Former Federal Reserve Chairman Bernanke for many, many years talked about the saving glut. The saving glut is basically what you see here on the left side-the deficits. The saving 
Figure 3

Three-Month LIBOR Interest Rates

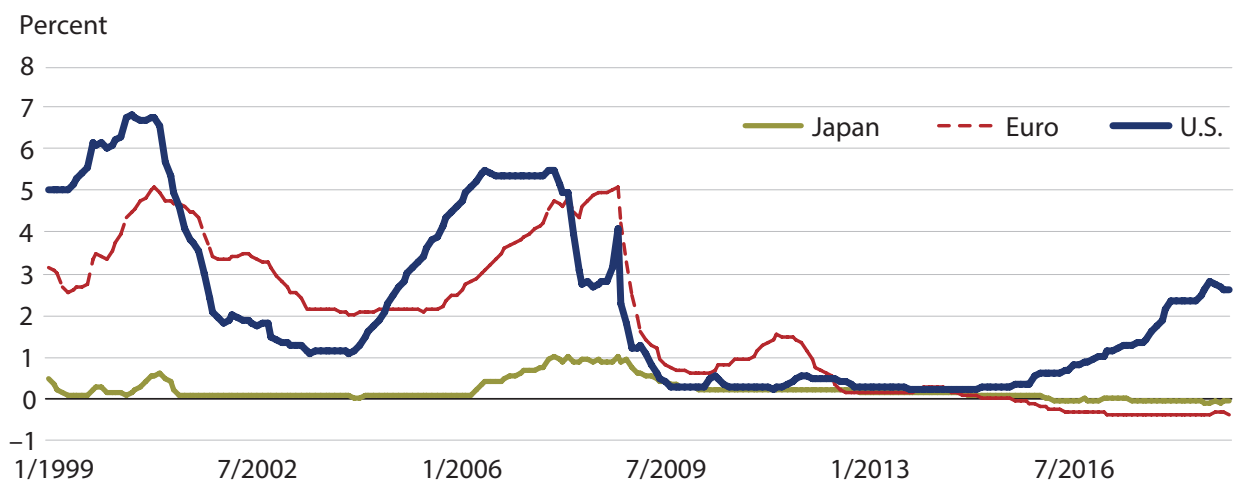

SOURCE: FRED ${ }^{\circledast}$, Federal Reserve Bank of St. Louis.

\section{Table 1}

Monetary Policy “Space"?

\begin{tabular}{lccc} 
Recession & $\begin{array}{c}\text { Starting federal funds } \\
\text { rate (percent) }\end{array}$ & $\begin{array}{c}\text { Lowest federal funds } \\
\text { rate (percent) }\end{array}$ & $\begin{array}{c}\text { Cumulative cut } \\
\text { (percentage points) }\end{array}$ \\
\hline 1990 & 8.25 & 3.0 & 5.25 \\
\hline 2001 & 6.50 & 1.0 & 5.50 \\
2007 & 5.25 & 0 & $\sim 5.25$ \\
\hline
\end{tabular}

SOURCE: Federal Reserve.

glut basically amounts to China saving a lot. We don't save as much. Surpluses in Asia and Germany also are offset by our deficit. That's an old story. Certainly, it's a story that carried weight in the 1980s. It began in the 1990s, it continued in the 2000s, and it has continued to the present.

What is relatively new is that in addition to the old flow problem, we now have more of a stock problem, meaning we are adding debt when our relative standing in terms of global indebtedness has notched up considerably. I will return to this issue later when I talk about what we can expect over the medium term for the U.S. dollar as a reserve currency.

Again, fiscal space is much more limited now for the advanced economies than it was at the time of the global financial crisis. I would argue that monetary policy space is also much more limited for obvious reasons. As shown in Figure 3, Japan has had negative interest rates for some time. Europe has had negative interest rates for some time. And for the United States, which is the outlier with positive interest rates, in the past, the average decline in the federal funds rate to combat recession had been 600 basis points (Table 1). This is something that we 
Figure 4

Global Annual Export Growth, 1928-2009

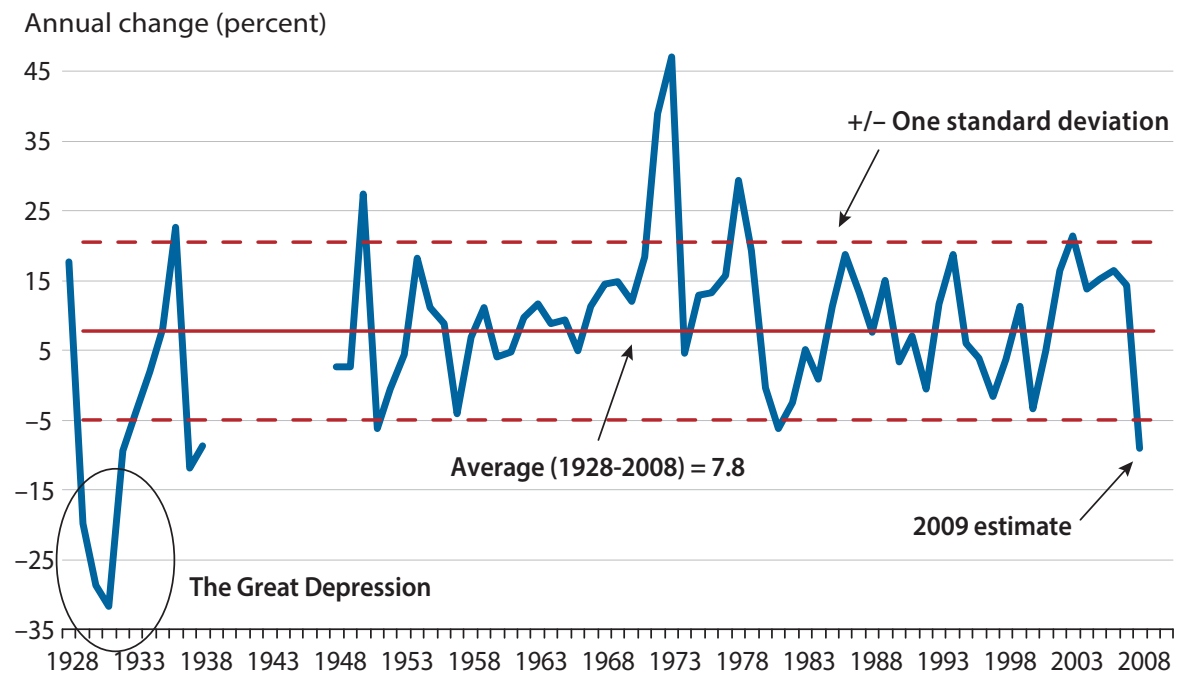

SOURCE: Reinhart and Rogoff (2009).

are not capable of delivering at the moment. So I think a real risk-and I will later conclude on this point-is that the advanced economies, collectively, are seriously constrained in terms of policy tools to deal with bad shocks. And that is any bad shock.

Let's turn to a shock that has been very much in the press-the trade wars. Figure 4 shows global annual export growth from 1928 to 2009. The figure ends in 2009 because it is taken from my book with Ken Rogoff. What are people worried about? Well, people are worried about a replay. In one potentially bad scenario, they're worried about a replay of the aftermath of the Smoot-Hawley tariffs and the trade war of the 1930s, which produced that record contraction in global trade.

Are we there? Are we close to there? What's going on with globalization? Well, let me make a couple of points about globalization. Actually, I wrote about this in Project Syndicate years ago. The peak in globalization was in the year before the crisis. Since the crisis, we've been moving toward a lower level of global growth in terms of trade (Figure 5). If you look at the decade before the global financial crisis, average trade growth volume was about 6 percent. In the decade after the crisis, it was less than half of that. This is not unique to the post-global financial crisis experience. This is not the first era of globalization we've had.

I think people don't realize that in the late 1800s to early 1900s, before World War I, we had a very globally integrated capital and goods and service system, albeit limited by the technology at the time. But that globalization was shot to pieces, first by World War I, then by the Depression, and certainly by World War II. Although the financial crisis did not have the extent of drama that the two world wars and major depression produced, it did put a big dent in global trade: It made countries running a current account deficit-such as Spain, Greece, 
Figure 5

\section{Global Trade Now in Negative Territory: Will This Time Be Different?}

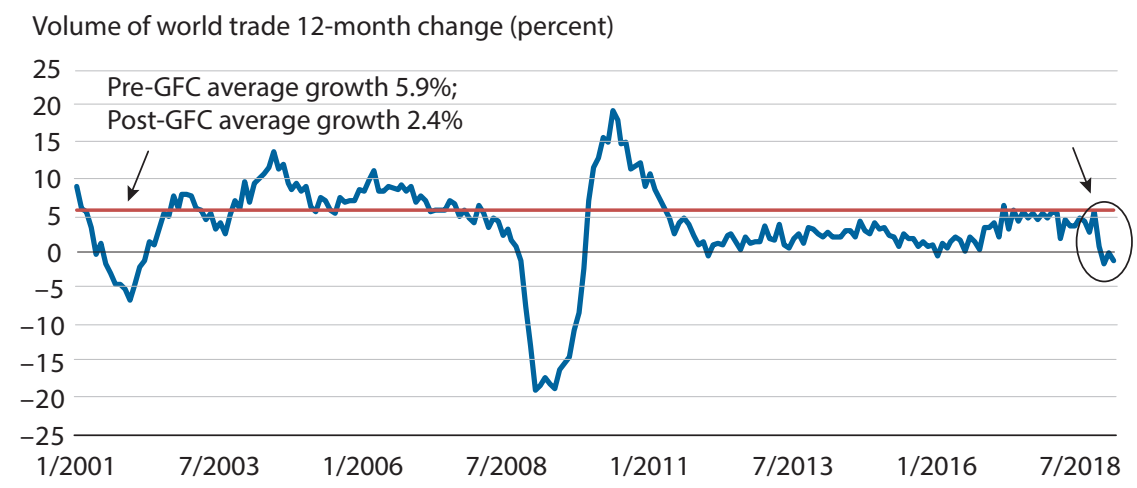

NOTE: GFC, global financial crises.

SOURCE: CPB Word Trade Monitor, February 2019.

Italy, Ireland, and others-realize that you can't finance a current account deficit from the rest of the world. So you have to watch. You have to import less. You have to look more to home. I think the issue of the rise of home bias dates back to the global financial crisis. I would note that Brexit was another major blow, and more recently, of course, what we're seeing in the trade wars is yet another.

What, in a nutshell, do I take away from the trade wars? Well, I found that my first assessment was completely wrong. If you had asked me in 2018 what I thought, I would have said the trade wars would be resolved a lot quicker, that it would be more of a NAFTA-type situation with a swifter resolution. It wasn't. It isn't. And it's my view now that it's not likely to be because what I've seen is that, over the course of this period, it's become not just about trade, but about geopolitical issues, about security issues and all kinds of issues that are unlikely to be resolved entirely with a handshake. So I think because of the electoral cycle in the United States, we are going to get some news, some deliverables on trade, but not a resolution. And certainly, I'm not looking for a return to the pre-crisis globalization era.

Let's continue on our global tour of advanced economy risks. I just returned from Europe. I was in Paris giving a talk there last week, and always the question is, what do you think are the weak points? Well, I think one can't talk about the next crisis in Europe without really making the point that the previous crisis hasn't been resolved for all of Europe. If you look at Figure 6, two things stand out: Financial crises produce a recession, a drop in per capita GDP, but ultimately countries recover. The recovery is pretty dramatic for Korea, but for Italy and Greece, it's nonexistent. If you take the level of Greek GDP or Italian per capita GDP today, it is below what it was in 2007. And if you take the International Monetary Fund (IMF) projections out to 2024, even by 2024, per capita income in Greece and in Italy will still be below what it was in 2007. That is a pocket of weakness that I think will continue to be a source of both tension and recurring bouts of global uncertainty when we talk about Europe. 
Figure 6

\section{Post-Crisis Recovery (or Lack Thereof in Southern Europe): Unresolved Debt Overhangs}

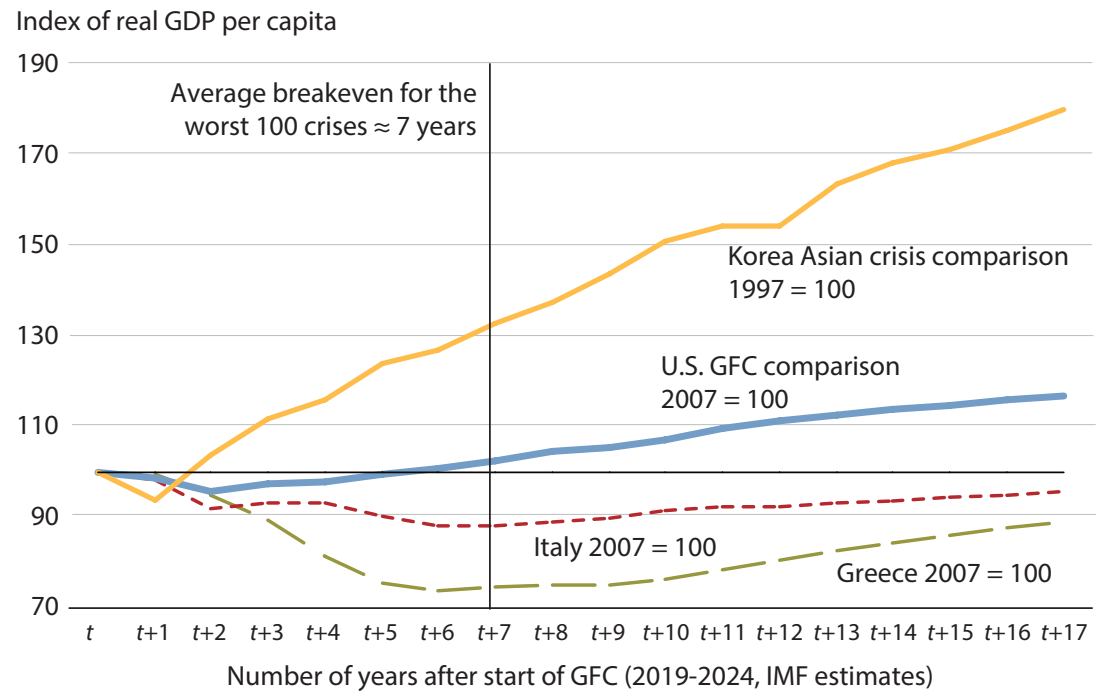

NOTE: GFC, global financial crisis.

Figure 7

Federal Funds Rate and Financial Conditions

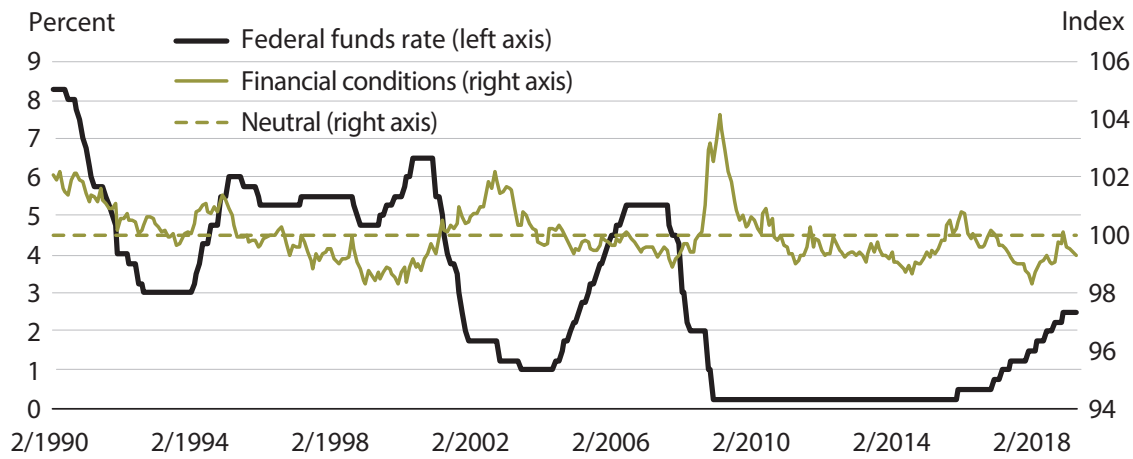

SOURCE: Federal Reserve and Goldman Sachs, accessed via Bloomberg, May 13, 2019.

I say "global uncertainty" because if you go back to 2018, every time the new Italian government made an announcement about possibly leaving the euro or contemplating not servicing debt, those comments translated into an appreciation in the dollar. A depreciation in the euro and an appreciation in the dollar is bad news for emerging markets that have dollar debts. It is a global shock. Let's now move on to yet another but very different type of risk.

U.S. financial conditions remained fairly accommodative through 2018 (Figure 7, black line). Look, for instance, at the financial conditions index that Goldman Sachs publishes 


\section{Figure 8}

\section{Yield Ratios: Risky Yields Relative to Corporate Debt Yields}

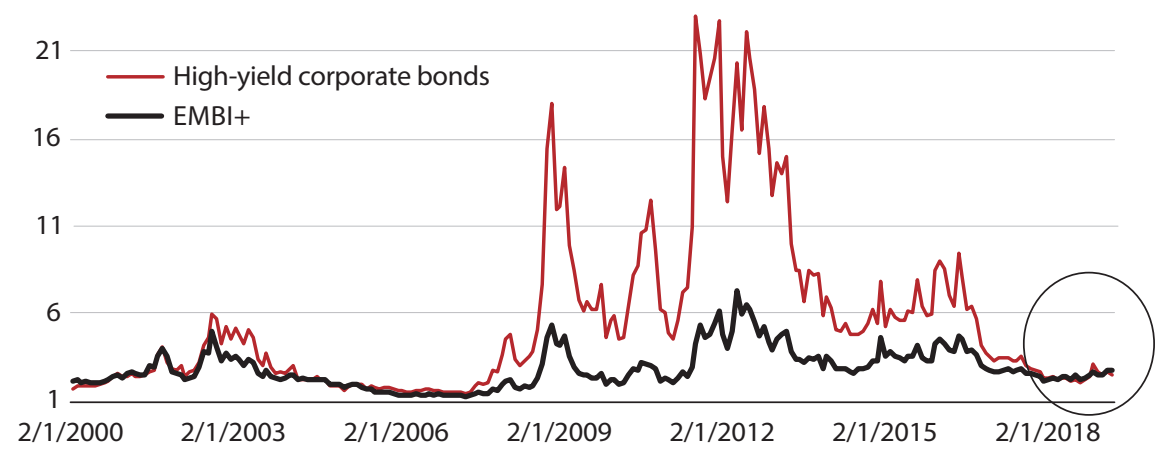

NOTE: EMBI+, J.P. Morgan Emerging Bonds Index.

SOURCE: Bloomberg and author's calculations.

(Figure 7, green line). I do not suggest that this is, by any means, the be-all end-all liquidity measurement of financial conditions. But by and large, the point I'm making here is that financial conditions, on the whole, up until the end of 2018 were relatively accommodated. And that, in turn, also contributed-in a world of low yields-to the eternal search for yield. I have done work going back to 1815 on the search for yield (Reinhart, Reinhart, and Trebesch, 2016): The search for yield is eternal. And it drove investors into high-yield corporate debt and, notably, comparatively newer instruments like collateralized loan obligations (CLOs).

I think we should pause a minute and think about what kinds of risk the honeymoon that we're seeing or have seen in these episodes is bringing to the table. Concretely, CLOs have some similarities to the mortgage-backed security problem in that they're not only attracting local interest but also global interest. In other words, foreign banks: Japanese banks and European banks are coming into the CLO market, which also potentially means that if that market sours, there will be global spillovers into other markets. Let's be clear: I'm not suggesting comparable magnitudes, but magnitudes in some dimension reminiscent of 2008-09.

I always remind people that German banks did not get into trouble in 2009 because they had a real estate bubble in Germany. They did not have a real estate bubble. They got into trouble because they had bought U.S mortgage-backed paper. So there's some scope there for an international contagion dimension.

There is also a worrisome trend: The quality of the borrowers and the quality of the covenants of these loans have been deteriorating. And that is also reminiscent of the run-up to the global financial crisis in which the earlier tranches of the mortgage pools were better quality than the later tranches. Just to be clear, what I'm saying is that, historically, emerging market yields-emerging markets, high-risk debt-have moved together with corporate high-yield debt (Figure 8). What we have seen in the last year and a half is that emerging market yields on the whole went higher while-at the same time-corporate yields went lower. 
Figure 9

\section{Foreign Exchange Reserve Ratios and the Currency}

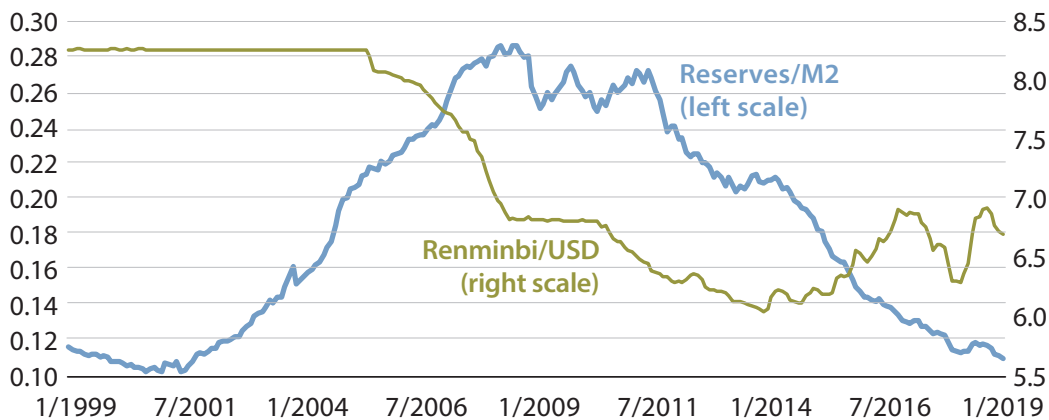

NOTE: USD, U.S. dollar.

SOURCE: FRED ${ }^{\circledR}$, Federal Reserve Bank of St. Louis.

So the question to you is this: What does this mean? Are we overpricing-overestimatingthe risks in emerging markets, or are we underestimating the risks in the corporate sector? The arguments I've made thus far is the latter, and that's the convergence that I'm showing in Figure 8.

Let's turn to emerging markets, specifically China, which by almost any metric is the size of the U.S. in the global economy. So we're talking about the world's second-largest economy and, depending how you measure it, in some instances the same size as the U.S. economy. The same points that I made about advanced economies having more-limited ammunition, I am going to make about China - and not about fiscal policy but about monetary policy.

Let me clarify. One of the concerns we've had when discussing the potential for a global slowdown is not just that the United States appears to be slowing or that Europe appears to be slowing, but that China also appears to be slowing - and slowing big-time. We should be concerned, again, because China is the world's second-largest economy. And a level of comfort is usually drawn from the idea that it can provide stimulus. And indeed, China is providing fiscal stimulus to the tune of about 1.75 percent of GDP. However, I don't think it's reasonable to expect China to provide fiscal stimulus and monetary stimulus, which for them is credit creation-meaning providing accessible credit to the corporate sector, to exporters, to banks, and so on.

Let me explain. In 2008-09, China really did record-by almost any metric-fiscal stimulus and monetary stimulus. At that time, however, China was growing double digits. They had large capital inflows. They were accumulating U.S. Treasuries. They were accumulating reserves. They were trying to lean against the wind to avoid a renminbi appreciation. That is not where they are now.

Figure 9 shows international reserves converted into renminbi, divided by M2 (the blue line). What this indicator shows is that China has gone through the full phase of the capital flow cycle. (This indicator goes back to work that Graciela Kaminsky and I [Kaminsky and 
Figure 10

General Government Debt: Emerging Market and Middle-Income Economies, 1880-2023

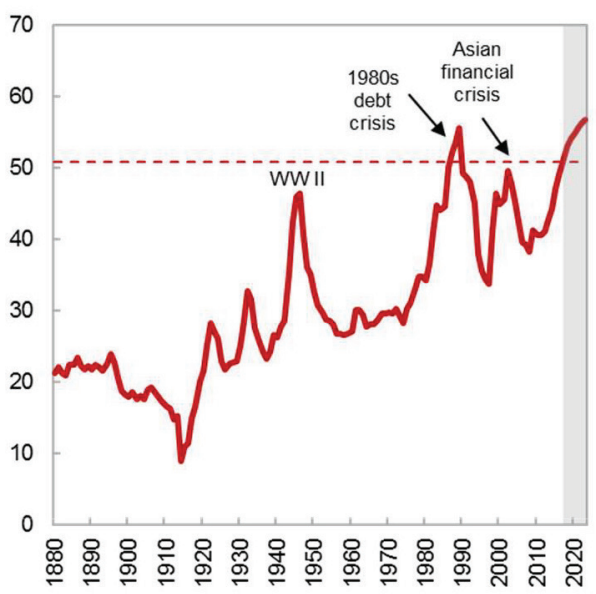

SOURCE: Bredenkamp et al. (2019); https://www.imf.org/en/News/Seminars/Conferences/2018/05/24/sovereign-debta-guide-for-economists-and-practitioners.

Reinhart, 1999] did on indicators of the capital flow cycle and indicators of financial crises many, many years ago.) China had a surge in inflows associated with the boom, and it is in the outflow phase.

In other words, a country facing capital outflows and trying to maintain a more-or-less stable currency can only do three things. One, they can try to stabilize the exchange rate by losing reserves (i.e., selling their dollar holdings), which China's been doing, intervening to stabilize their renminbi. Two, they can tighten controls, which it's also been doing. This is related to the turmoil in Hong Kong. And three, they can keep tight money, which basically goes to the point that I was making. I don't think China has the ability right now to really engage in very stimulative monetary policy, at least nothing like what it's done in the past.

This is a global risk because China's footprint, as we shall also see, among emerging markets is nothing less than major. We hear a lot about the impact of trade, but China also has a huge impact through finance. And I end my commentary on China by saying that if you do backward exercises, meaning you look at China's trading partners, whether they're commodity producers or other Asian economies that export intermediate goods to China, and you look at how much they've slowed, you would not infer that the remnibi-to-U.S. dollar slowdown (Figure 9, green line) has only been to 6 or 6.5. You would infer that the slowdown is even greater. So I think that that is also a serious-bigger, more protracted-Chinese slowdown that is also a serious headwind to the global economy.

Briefly, I'll also mention two other types of risk now moving out of the big countries and into emerging markets. Figure 10, which is taken from recent work (Bredenkamp et al., 2019) that I did for an IMF conference and volume, shows the indebtedness for emerging markets. Since we are comparing previous episodes, let's choose a relevant previous episode we all are 
Figure 11

The Rise of China as a Global Official Creditor, 1998-2018

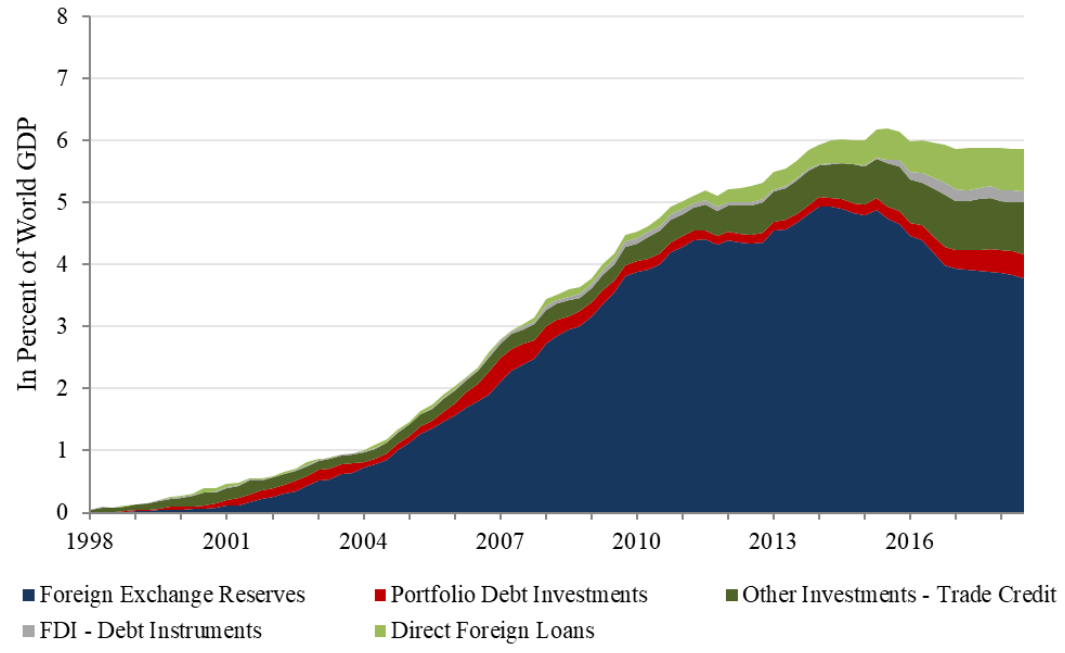

NOTE: FDI, foreign direct investment.

SOURCE: Horn, Reinhart, and Trebesch (2019).

familiar with: the Asian crisis or the crisis of the 1980s. I would note emerging markets are in more vulnerable territory. Not just Turkey. Not just Argentina. But emerging markets as a whole have slowed down dramatically, largely as a consequence of the slowdown in China and partly, also, as a consequence of dollar strength. These countries tend to have a high share of either corporate or public debt, or both, in U.S. dollars. So a dollar appreciation means higher debt servicing costs, which means more problems. But emerging markets are in more vulnerable territory than they've been in a while.

Finally, before talking about the long-term issue, I mentioned that China's role in emerging markets is not just the vast expansion in trade. It's been an expansion in finance. (Figure 11) Right now, Chinese lending to the emerging world is bigger than all such lending from the Paris Club and the IMF combined-the official creditors, all the major advanced economies, that lend bilaterally to emerging markets. China's loans are bigger than all of those and the IMF and the World Bank combined.

Well, what's the problem? To say that the problem is that China's lending is opaque would be an understatement. It is not recorded by the Bank for International Settlement. It is only partially recorded in the World Bank database. It is a thorn in the side of the IMF. The IMF's program with Pakistan - a big to-do-was actually trying to find out how much debt Pakistan owed China. You can't do debt sustainability exercises that are meaningful if you don't know what the outstanding level of debt is.

Hidden debts are a big problem for countries that have borrowed from China. And if you're an investor, you also worry about hidden debts: If you're buying an Ecuadoran or Angolan bond and you're pricing them, thinking that the external debt of that country is, let's say, 40 
Figure 12

Total External Debt: Officially Reported (World Bank) and “Hidden Debts” to China, 2000-18
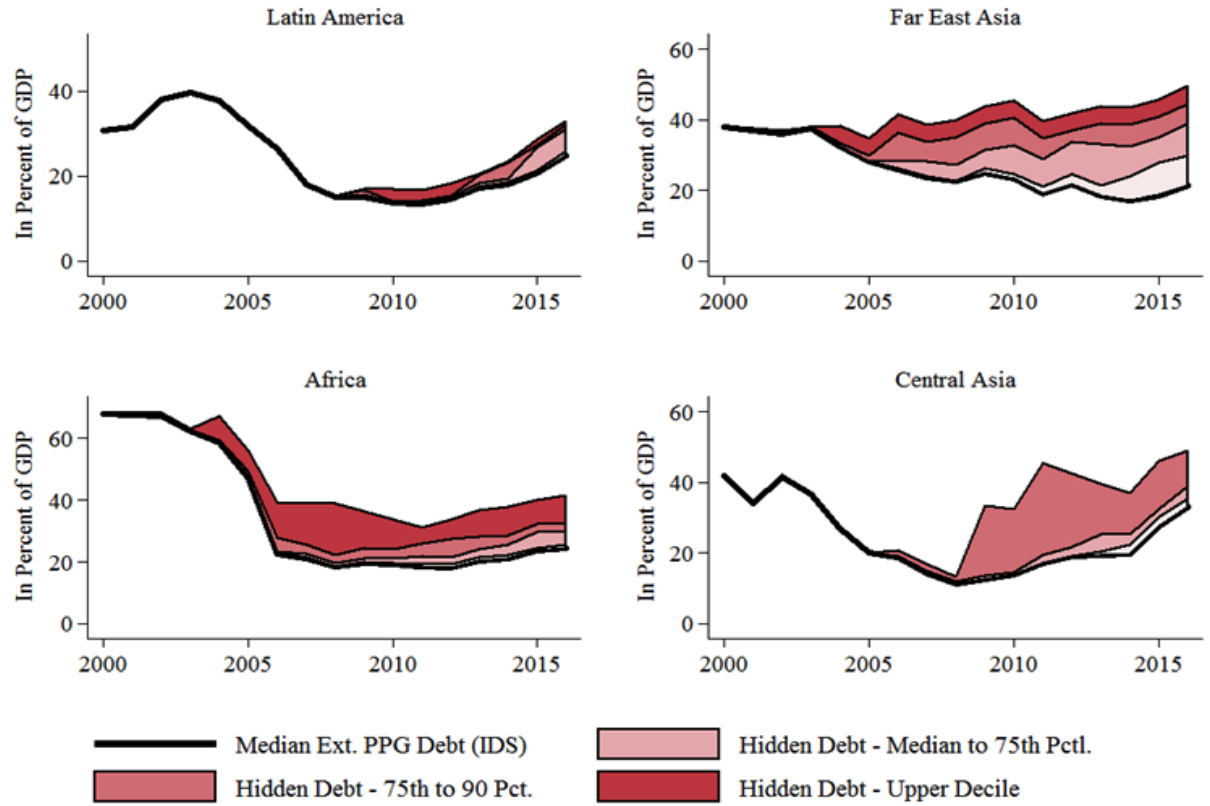

NOTE: Median ext. PPG debt (IDS), median external, public and publicly guaranteed debt to GDP according to the World Bank's International Debt Statistics.

SOURCE: Horn, Reinhart, and Trebesch (2019).

\section{Table 2}

\section{Countries Restructuring External Chinese Debt Since 2011}

$\begin{array}{cccc}\text { Tanzania } & \text { Cuba } & \text { Sudan } & \text { Ecuador } \\ \text { Bangladesh } & \text { Seychelles } & \text { Venezuela } & \text { Zambia } \\ \text { Cote D'lvoire } & \text { Togo } & \text { Ukraine } & \text { Sri Lanka }\end{array}$

percent, and it's really 60 percent, you have a problem. And if also you don't know who the senior creditors are, you have a problem.

The issue that I'm raising here is based on ongoing work with Christoph Trebesch and Sebastian Horn (Horn, Reinhart, and Trebesch, 2019) (Figure 12). The issue is that these are economies that are not systemic. On the whole, they tend to be small. Collectively, they're not trivial either. And there is a problem of seriously underreported debts. The World Bank database captures only about 50 percent of China's loans to these countries. So with that uplifting note, let me turn to one final point. By the way, it is not a hypothetical that these debts cause problems. If you look at sovereign restructurings, we've had about a dozen sovereign restructurings already of Chinese debt that we know of (Table 2.) There may be more. 
Figure 13

Role of the Dollar and the Global Footprint of the U.S. Economy, 1950-2016

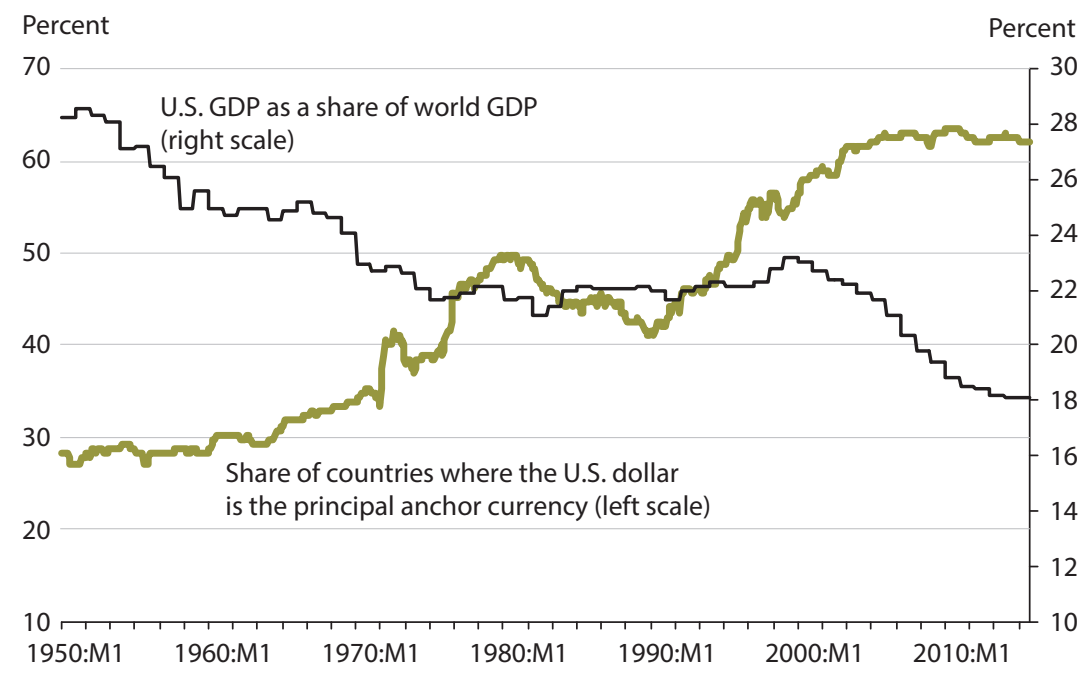

SOURCE: Ilzetzki, Reinhart, and Rogoff (2019).

Figure 14

Role of the French Franc and Deutsche Mark 1950-1998 and Euro 1999-2016

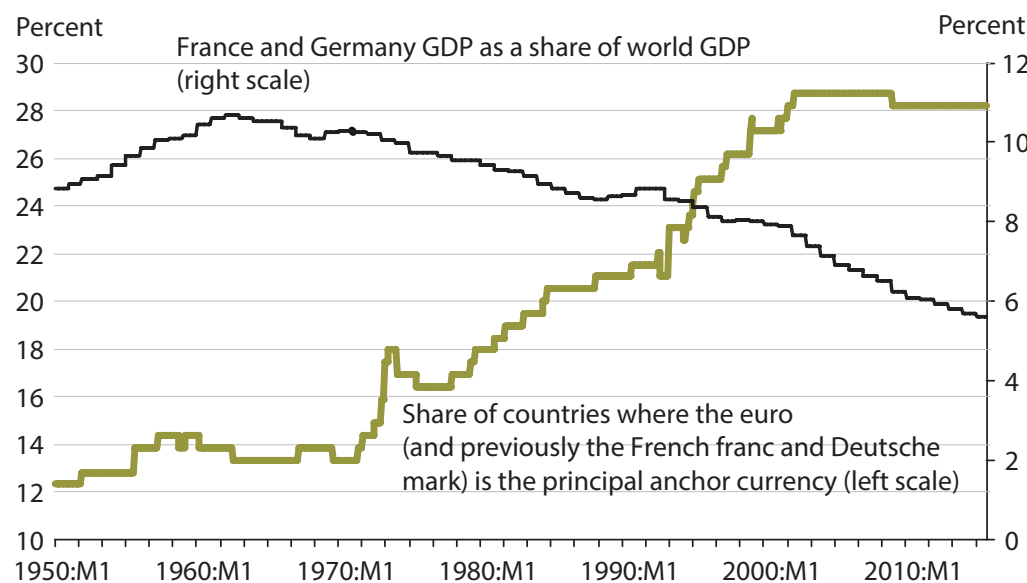

NOTE: Notice the difference in scales in comparison with those for the U.S./U.S. dollar in Figure 13.

SOURCE: Ilzetzki, Reinhart, and Rogoff (2019).

I now turn to my last topic: What about the long horizon? I talked about U.S. debt rising. I talked about the twin deficit problem. I talked about the COB projecting that, even with rates roughly where they are, there is still a debt sustainability problem. Well, let me bring up an old topic-the Triffin dilemma. It arose in the late 1960s when the United States was borrowing 
heavily to finance the Vietnam War. And at the time, which was still under the Bretton Woods system, countries held dollar reserves and stabilized against the dollar. There was demand for U.S. dollar debt: Remember, countries and central banks do not buy greenbacks. They buy debt. The essence of the Triffin dilemma is that for domestic considerations, you would like to be more circumspect about your debt levels. The external dimension is that if you're the world's reserve currency, you have a lot of rope to hang yourself with: The rest of the world is willing to buy a lot of debt to sustain what may appear like a strictly domestic unsustainable situation.

How did the Triffin dilemma resolve itself last time? It resolved itself with the breakdown of the Bretton Woods system and dollar depreciation. The dollar depreciated versus the Deutsche mark by about 55 percent. Figure 13 is from Ilzetzki, Reinhart, and Rogoff (2019). The solid line shows one of our measures of the demand for dollars, or dollar debts, from the rest of the world; this is the share of countries where the U.S. dollar is the main anchor currency. The dashed line shows U.S. GDP as a share of global GDP. The modern Triffin dilemma, if you will, is that the U.S. share in the global economy is getting smaller while the demand for U.S. assets is getting bigger. (Also see Figure 14.)

How do you reconcile the two? Last time, the reconciliation was, we can say, a devaluation because it was in an era of fixed exchange rates. The question now is, will this mean that once again the equilibrating factor to impose a tax, if you will, on foreign bond holders is a secular depreciation of the dollar? Now, every time you say "secular depreciation of the dollar" at a time of uncertainty, you know you're going to be wrong. You just know you're going to be wrong because every time you say "dollar depreciation" and there's uncertainty, you have to face the flight to quality, the flight to the dollar. Why are we in a situation where the long-term secular trends tell you one thing and in the short run something else happens? I would have to say that at the moment, it's a lack of alternatives.

The fact is that the euro hasn't delivered what everyone hoped it would deliver. There is no liquid euro debt market. You have Italian debt. You have Greek debt. You have a more fragmented system. The renminbi is not a convertible currency. And given the trends that I described earlier for China, it's clear that China has been scaling back on its ambitions to make it an international currency relative to what their ambitions were six years ago.

Is the dollar going to depreciate on a secular basis, or are we going to continue to have dollar appreciation every time global uncertainty pops up? Because if you look at every moment of turmoil, it's usually characterized by a flight into U.S. assets and an appreciating dollar. 


\section{REFERENCES}

Bredenkamp, Hugh; Hausmann, Ricardo; Pienkowski, Alex and Reinhart, Carmen M. "Challenges Ahead," in Ali Abbas, Alex Pienkowski, and Kenneth Rogoff, eds., Sovereign Debt: A Guide for Economists and Practitioners. Chapter 9. London: Oxford University Press, 2019; https://doi.org/10.1093/oso/9780198850823.003.0010.

Kaminsky, Graciela and Reinhart, Carmen. "The Twin Crises of Banking and Balance-of-Payments Problems." American Economic Review, June 1999, 89(3), pp. 473-500; https://doi.org/10.1257/aer.89.3.473.

Horn Sebastian; Reinhart, Carmen M. and Trebesch, Christoph. "China's Overseas Lending." Unpublished manuscript, 2019.

Ilzetzki, Ethan; Reinhart, Carmen M. and Rogoff, Kenneth. "Exchange Rate Arrangements in the Twenty-First Century: Which Anchor Will Hold?" Quarterly Journal of Economics, May 2019, 134(2), pp. 599-646; https://doi.org/10.1093/qje/ajy033.

Reinhart, Carmen M.; Reinhart, Vincent and Trebesch, Christoph. "Global Cycles: Capital Flows, Commodities, and Sovereign Defaults, 1815-2015." American Economic Review, May 2016, 106(5), pp. 574-80; https://doi.org/10.1257/aer.p20161014.

Reinhart, Carmen M. and Rogoff, Kenneth S. The Time Is Different: Eight Centuries of Financial Folly. Princeton University Press, 2009; https://doi.org/10.2307/j.ctvcm4gqx. 
